\title{
Hirschi's Social Bonding Theory Nearly 45 Years Later: A comparison of a traditional, contemporary and hybrid model
}

\author{
Peter P. Cassino and William S. Rogers ${ }^{1}$
}

The present study investigates the following aspects of Hirschi's (1969) social bonding theory: attachment to parents, attachment to school, involvement in conventional activities, and the belief bond. Specifically, a goal is to fill a gap in the literature by comparing Hirschi's traditional measures to contemporary measure using a single independent national sample of American high school students. Results indicated that the Hybrid Model was the strongest and the Contemporary Model was the weakest. Thus, it is argued that Hirschi's traditional measures predict the largest amount of selfreport general deviance. [Article copies available for a fee from The Transformative Studies Institute. E-mail address: journal@transformativestudies.org Website: http://www.transformativestudies.org (C2016 by The Transformative Studies Institute. All rights reserved.]

KEYWORDS: Hirschi, Deviance, Delinquency, Juvenile, Youth.

Travis Hirschi (1969) developed social bonding theory. The main premise of his argument was that conformity, not deviance, is what needs explaining. The present study further investigated the following aspects of Hirschi's social bonding theory: attachment to parents, attachment to school, involvement in conventional activities, and belief in the law/legal system. The goal of the present study is to fill a gap in the literature by

\footnotetext{
${ }^{1}$ Peter P. Cassino, Ph.D., is a researcher for the Center for Leadership in Public Service and an Assistant Professor of Criminal Justice at Fisher College. Dr. Cassino received his Doctorate in Sociology from Northeastern University. He teaches courses in criminological theory, research methodology and statistical analysis. His research interests include control theory, hate crime, and institutional anomie theory. Address correspondence to: Peter P Cassino, Fisher College, Boston, Massachusetts 02116; e-mail: pcassino@fisher.edu.

William S. Rogers, Ph.D., is a Full Professor of Psychology at Mount Washington College. Dr. Rogers received his Ph.D. from Texas A\&M University in psychology. His research interests include domestic violence, aggressive driving, attachment theory and evolution.
} 